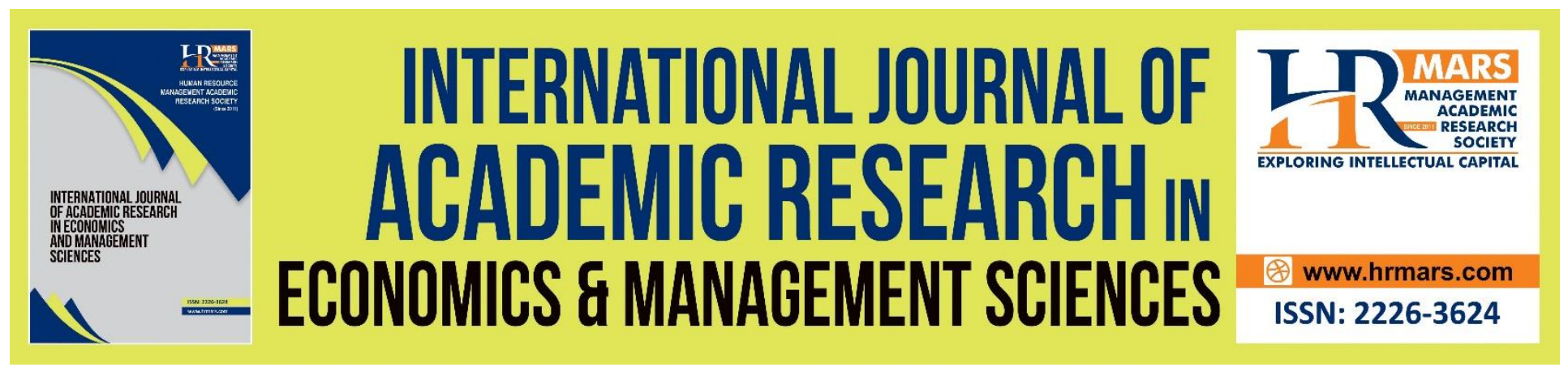

\title{
Enhancing the Role of Zakat Institutions Through Good Corporate Governance for Economic Sustainability: A Case from Majlis Agama Islam Melaka \& Pusat Zakat Melaka
}

A'ieshah Abdullah Sani, Khairunnisa Abd Samad, Amilia Saidin, Siti Azrina Adanan, Khair Syakira Bustamam \& Siti Nurulhuda Mamat

To Link this Article: http://dx.doi.org/10.6007/IJAREMS/v10-i3/10984

DOI:10.6007/IJAREMS/v10-i3/10984

Received: 08 July 2021, Revised: 30 July 2021, Accepted: 20 August 2021

Published Online: 26 September 2021

In-Text Citation: (Sani et al., 2021)

To Cite this Article: Sani, A. A., Samad, K. A., Saidin, A., Adanan, S. A., Bustamam, K. S., \& Mamat, S. N. (2021). Enhancing the Role of Zakat Institutions Through Good Corporate Governance for Economic Sustainability: A Case from Majlis Agama Islam Melaka \& Pusat Zakat Melaka. International Journal of Academic Research in Economics and Management and Sciences, 10(3), 287-300.

Copyright: (c) 2021 The Author(s)

Published by Human Resource Management Academic Research Society (www.hrmars.com)

This article is published under the Creative Commons Attribution (CC BY 4.0) license. Anyone may reproduce, distribute, translate and create derivative works of this article (for both commercial and non-commercial purposes), subject to full attribution to the original publication and authors. The full terms of this license may be seen at: http://creativecommons.org/licences/by/4.0/legalcode

Vol. 10, No. 3, 2021, Pg. 287 - 300

http://hrmars.com/index.php/pages/detail/IJAREMS

JOURNAL HOMEPAGE

Full Terms \& Conditions of access and use can be found at http://hrmars.com/index.php/pages/detail/publication-ethics 


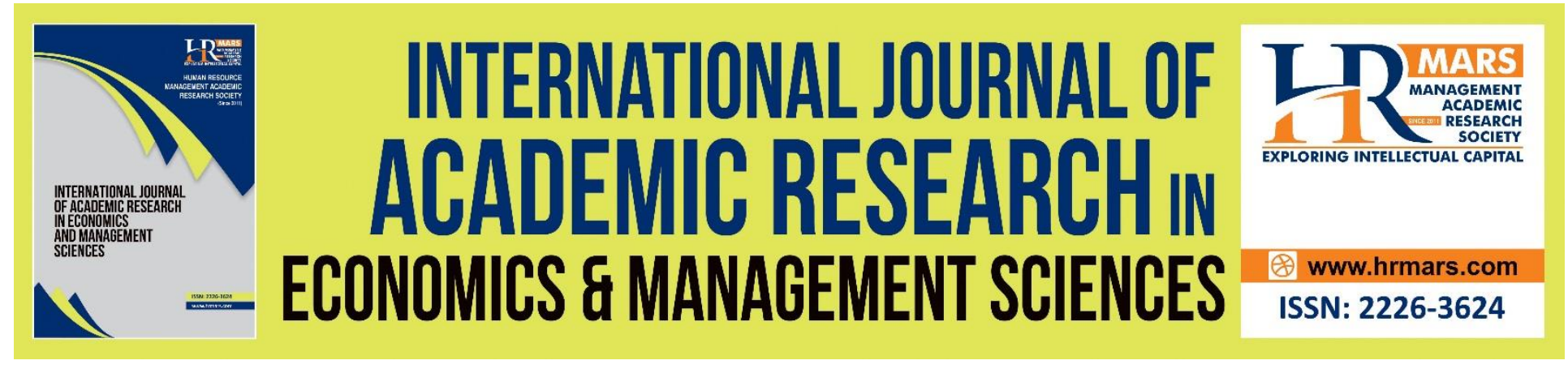

\title{
Enhancing the Role of Zakat Institutions Through Good Corporate Governance for Economic Sustainability: A Case from Majlis Agama Islam Melaka \& Pusat Zakat Melaka
}

\author{
A'ieshah Abdullah Sania,c, Khairunnisa Abd Samad ${ }^{\mathrm{b}, \mathrm{c}}$, Amilia \\ Saidina, Siti Azrina Adananª, Khair Syakira Bustamamª \& Siti \\ Nurulhuda Mamat ${ }^{\mathrm{a}}$
}

aFaculty of Accountancy, Universiti Teknologi MARA Cawangan Melaka, baculty of Business Management, Universiti Teknologi MARA Cawangan Melaka, 'Centre of Islamic Philanthropy and Social Finance (CIPSF), Universiti Teknologi MARA Cawangan Melaka

\begin{abstract}
Zakat institutions play a crucial role within the Islamic financial system to maintain the prosperity in Muslim communities. However, inefficient zakat management and low zakat payment compliance identified as main obstacle faced by the institutions. Thus, good governance implementation is noteworthy to alleviate the problems for long-term economic sustainability. Hence, the purpose of this study is to examine the implementation of good governance framework in zakat institution which comprise of their accountable board and leadership (in zakat administration), information transparency (in zakat institution website), disclosure practices (in financial reporting) and stakeholder management (in zakat distribution practices) of Majlis Agama Islam Melaka (MAIM). This study uses content analysis and descriptive method by analysing information disclosed in MAIM's 2015 to 2019 annual report and Pusat Zakat Melaka (PZM) website. The result of this study shows that both institutions generally embraced good governance practices but not at their optimum level. There are deficiencies in zakat information on website to demonstrate their validity in ensuring effective and efficient zakat management and distribution. The implication of this study could deliver positive impact in zakat institutions when good governance is being practiced at optimum level and enhance higher zakat compliance in alleviating poverty among Muslim society.
\end{abstract}

Keywords: Good Governance, Zakat Institution, Compliance, Sustainability, Disclosure

\section{Introduction}

The zakat institution plays crucial role in upholding the image of Islamic financial system, thus the need to implement the good governance. Indeed, the good governance is emphasized as one 
of the significant goals under Sustainable Development Goals (SDGs) no.16 to promote "Peace, Justice and Strong Institution" and sustain the nation's economic development. The role of zakat institutions played a significant role in the socioeconomics, social and moral development of Muslim societies throughout Islamic history. The success of zakat has been evidenced during the early days of Islam and it achieved at the highest achievement during the rule of Umayyah Chaliph, Umar bin Abdul Aziz whereby none of the Muslim societies in Madinah entitled to receive zakat money since all of them are qualified for zakat payers (Sawmar \& Mohammed, 2021).

Generally, the major roles of Zakat institutions are focusing on zakat collection from all categories of zakat payers (i.e. individuals and companies) and zakat distribution to the eligible recipients (i.e. asnaf). Efficient management of zakat institutions from the aspects of collection and distribution is crucial so that resources can be pooled to ensure social justice among the people (Saad, Abdul Azis \& Sawandi, 2014). Zakat payers, specifically, and other stakeholders are keen to know how the zakat fund is distributed. Zakat recipients are also eager to know how efficient the process of zakat distribution is. The zakat management institution itself wants or needs to know the extent of its effectiveness and efficiency in managing the zakat funds entrusted to it. The issue of lack of transparency in disclosing zakat information to public as well in terms of how efficient the zakat distribution been conducted by zakat institutions become questionable by the Muslim society today (Adiwijaya \& Suprianto, 2020). Hence, it motivates this study to look further on the good governance practiced by zakat institutions in order to address this issue. It is known that by enhancing the roles of zakat institutions through good corporate governance principles (consist of transparency, accountability, responsibility and fairness) are able to improve public confidence and economic sustainability for the Muslim society as a whole. The positive result of economic sustainability could be portrayed by increase in zakat compliance and efficient in zakat distribution which is consistent under SDGs no. 16.

Zakat institution governance is being introduced to measure the performance of zakat institutions as good governance has become the critical issues in order to maintain the reputation of zakat institutions since the rules and administration of this institutions are not standardized in Malaysia. Amalia (2019) confirmed that even though the principles of good governance in zakat institutions in Indonesia has been well implemented in some aspects; not in total (the highest dimension is transparency, followed by accountability, responsibility, independence and fairness), the zakat compliance is still not at optimum level due to lack of public trust in zakat institutions. Hence, strengthening zakat institution governance is significant as zakat administration required to have continuous improvement in their institution to enhance its reputation and boost up the public confidence. The implementation of good zakat institution's governance could assist the authorities to formulate policy or strategy to ensure the efficiency of zakat administration because of their pivotal role in the Muslim society.

Based on the current needs for continuous improvement by zakat institutions and fulfilling the demand of the public that require good governance practice, hence this study is aims to examine the implementation of good governance framework in zakat institution which consist of their accountable board and leadership (in zakat administration), transparency information (in zakat institution website), disclosure practices (in financial reporting) and stakeholder management (in zakat distribution practices) as being practiced by Majlis Agama Islam Melaka (MAIM) and Pusat Zakat Melaka (PZM). These governance aspects are considered crucial for 
improving the effectiveness and efficiency of zakat institutions. This is a case study research whereby the focus of good governance framework and performance for zakat institutions is being explored at Melaka state only from year 2015 until 2019 since in Malaysia, zakat management and institutions is being administered by each of the state government respectively.

The findings from this research found that overall, the performance of zakat collection in Melaka has been improving from year 2015 to 2019. It shows that the level of zakat compliance has been increase from year to year, proving that the number of zakat payers also increasing especially from the individuals. In terms of good governance principles, the result portrays the disclosure level of governance practices is not sufficient for the first three years (2015 to 2017); but has been improving thereafter. This study could bring significant contribution for zakat institutions particular in Melaka to upgrade the governance disclosure by having a specific good governance report for the institution and facilitate the policymakers to assess the governance practice of zakat institutions transparently. As a result, the public confidence on zakat institutions could be rising and uphold positive reputation of the zakat institutions itself as a whole.

The structure of this paper is as follows whereby the second section provides a review of the relevant literatures. The third section is the methodology of the study following with the fourth section is the results of the study and discussion on zakat performance in terms of collection and distribution trend in Melaka for the recent five years (from 2015 to 2019) and disclosure of good governance framework as being practiced in MAIM and PZM. The final section concludes the paper and provides recommendations for future research.

\section{Literature Review}

The concept of governance encompasses a comprehensive system that focus on serving the best to all interested parties whilst fulfil the objectives of the organisation. The United Nation has formulated the SGDs for the global economic prosperity and development. The goal no.16 highlighted the importance of strong institutions focusing to develop effective, accountable and transparent institutions at all levels. Besides, the Organization of Economic Cooperation and Development (OECD, 2016) defines corporate governance as the "a set of relationship between a company's management, its board, its shareholders and other stakeholders." This indicates that the term covers not only the parties that within the organisation, but also including parties that are affected by the decision of that organisation. Besides, according to Malaysian Code on Corporate Governance (MCCG, 2012), the corporate governance is "the process and structure used to direct and manage the business and affairs of the company towards enhancing business prosperity and corporate accountability with the five ultimate objective of realising long-term shareholder value, whilst taking into account the interest of other stakeholders." This definition compliments to the earlier one which focuses on the interested parties' relationship without jeopardizing the important of achieving the organisation's goals.

The holistic definition of governance shows a significant emphasis on the process that was agreed upon and enforcement on the compliance. Thus, a good governance may view as a complex process among all related parties in embracing their different objectives and act to the legal rules and obligation. In order to achieve the principles of good governance, a framework of good governance had been developed and practiced by public organisation. For instance, the International Federation of Accountants and the Chartered Institute of Public Finance and Accountancy laid out the governance framework for public sector which comprises the principle 
of good governance, namely, integrity and the rule of law, participation or stakeholders' engagement, clarity of strategic vision, efficiency and effectiveness, capacity development, risk management and internal control and transparency and accountability. Another governance framework for an organisation as outlined by MCCG (2012) is focusing on the structure of the board of directors and its committee, integrity of financial reporting, importance of risk management as well as internal control. However, the challenges continue to exist in implementing such codes and principles (IFAC and CIPFA, 2014).

\section{Good Governance Framework in Zakat Institution}

Zakat institution is a non-profit organisation entrusted to receive, collect and distribute zakat funds using various mechanism to eligible recipients. The organisation has an obligation to manage properly the zakat funds in order to gain trust from the zakat payer and achieve a fair and equitable distribution. The wealth of zakat can be considered a productive asset when it is used to develop the Muslim economy (Hambali, Hamzah, Daud \& Johari, 2017). Hence, the main aim of zakat institution is to improve the socio-economic status of the recipients as the way of eradicating poverty and eventually increase the standard of living for poor Muslim.

The regulatory framework of zakat institution differs among Muslim countries. In Malaysia, management of zakat fund is institutionalized with the establishment of regulated zakat system. It is important to explore the various governance structure of zakat institution since the organisation control significant amount of financial resources (Abd. Wahab \& Abdul Rahman, 2011). Effective practice of a good governance among the zakat institution will promote nation building in the aspect of economy, social and moral of the society. When zakat is being manage efficiently, it would encourage the transfer of wealth from the rich to the poor, and ultimately increase productivity and alleviate poverty among Muslim society.

A good governance institution is when the organisation continues to be accountable, transparent and fair in their daily operation. Embracing good governance is essential for zakat institution to optimise their performance and reinforce trust among zakat stakeholders (Ahmad Sawmar and Mohammed, 2021). This includes the payment compliance on the part of zakat payers and fair distribution of the zakat institution. An adequate governance of zakat institutions comprises of effective and efficient of distribution aspect as well as existence of sufficient financial reporting (Adiwijaya and Suprianto, 2020). A study on the impact of attributes for good governance which are accountability, responsiveness, transparency and disclosures of zakat institution shows that there is significant impact towards reinforcing zakat recipients' satisfaction (Shazilli et al., 2012). Hence, based on updated MCCG 2017, this study will focus on four elements to assess the governance structure that is closely related for zakat institutions which are board and leadership, transparent information, disclosure practices and stakeholder management.

\section{Board and Leadership (Zakat Administration)}

A company or institution is formed as a separate legal entity with the aim to ensure proper management of power and liability. As for zakat institution, the mechanism of governance is reflected by the election of Board of Director and the Sharia Executive Board that oversight the business operation and undertake the fiduciary duties with due care, diligence along with avoiding conflict of interest. On the other hand, a group of management will manage zakat funds as well as disclosure of reliable and relevant zakat information. Besides, policies and procedure 
such as internal control applied will strengthen the proper implementation of this separate functions as to align with the organisation goals (Shazilli et al., 2012).

Transparency and accountability of the board is demonstrate by regular board meeting and the process of selecting the board members (Zadjuli, 2020). This is also supported by Saad et al. (2017) study where most of the zakat centres throughout Malaysia have a board of directors who undertake their responsibilities of holding board meetings, having audit work and elect committee. The composition of the board members for zakat institution should consists of experts and professionals from various fields such as Syariah, conventional law, Islamic banking and information technology. These experts can be notice based on their educational background, experiences and job training. Eventually, the existence of competent board as a governance factors would enhance the monitoring function and thus improve the efficiency of zakat institution (Abd. Wahab \& Abdul Rahman, 2011).

\section{Transparent Information (Zakat Institution website)}

Zakat institution should show transparent management to all related parties by providing sufficient access to zakat information for monitoring purposes as the institution is considered as non-profit organisation (Abd. Wahab \& Abdul Rahman, 2011). This practice is important as to establish accountable act by the zakat institution itself. The element of accountability is one of the good governance principles that would increase the effectiveness of zakat fund, shown by the effective process of approving the zakat application (Shazilli et al., 2012). Moreover, by publishing information through website also would increase the transparency principle that will build trust from zakat payers and zakat recipients.

One of the most popular communication channel use to obtain zakat information such as collection and distribution is through website (Ghazali, Abdul Wahab, Saad \& Mat Samsudin, 2020). Official website should ensure enough information available such as the process of zakat application, programs conducted, zakat distribution summary, method of zakat payment and other relevant data. However, there are some challenges in collecting relevant zakat information especially on the reporting aspects (Samargandi et al., 2018; Sapingi, Nelson \& Obid, 2018; Sulaiman, Che Cob, \& Ali 2015). A study found that only $7 \%$ of the respondent gathered zakat information through official zakat website while other channel used are through relative friends, newspaper, memo and radio (Raja Ahmad, Amiruddin Othman, \& Salleh, 2015). This is also supported with another findings where there are a few zakat institution did not publish their annual report in the website (Endut et al., 2020).

\section{Disclosure Practice (Zakat Report)}

Nowadays, the disclosure of financial and non-financial information has become increasingly demanding due to the occurrence of financial scandals such as misappropriation and falsification of data (Omar \& Abu Bakar, 2012). As for a non-profit organisation, disclosure of information will enlighten their fundraiser, recipients and government regarding the organisation's activities. The existence of quality financial reporting through annual report and effective internal control is viewed to be one of the most important aspects which support the governance structure of zakat information (Naz'aina, 2015). Financial reporting should consist of information pertaining the ability of zakat institution in using its economic resources and fulfilling its obligation. Example of adequate disclosure of relevant information in the annual report which is important to the users 
for the purpose of serving Allah SWT are amount of zakat collection and distribution, the measurement used and ruling of shariah supervisory board (Abdul Rahman, 2007).

Although there is no statutory obligation for zakat institution to disclose their annual report as compared to companies listed on Bursa Malaysia, however their voluntary disclosure may influence the confidence level and trust of zakat payers. There are no proper requirement and guidelines for the zakat institution concerning on the amount of information disclose. It is evidence by a study among zakat institution in Malaysia revealing no uniformity in reporting of financial statement, ranging from no financial data disclosed until a complete set of audited financial statements (Endut et al. 2020). Lack of disclosure of zakat distribution has cause dissatisfaction among the zakat payers until to the point that some of them choose to pay directly to asnaf or not paying zakat at all. Annual report should be one of the public relation documents designing to encourage zakat payers by providing sufficient, relevant and accurate information.

\section{Stakeholder Management (Zakat Distribution)}

The efficiency is improved when more output is generated using the given inputs and available technologies. As for zakat institution, it is deemed efficient when the organization can provide more services for society through fair and equitable distribution of zakat funds (Ahmad et al., 2015). The evaluation of zakat efficiency is crucial in improving proper distribution of zakat funds and in return, contributing to the development of ummah and the country by providing resources of consumption and needs of the spirituals of the giver. It is evidence that zakat institution still plays an important role in zakat distribution by the responsibility of zakat officer which is the appointed agent (Shazilli et al., 2012). The governance principle of fairness must be adopted along with the legal framework of shariah requirements on zakat.

However, there are many issues arise in zakat institution specifically on distribution aspects (Nazri, Abd Rahman \& Omar, 2012). A study revealed that there are circumstances where zakat funds had been misused and occurrence of fraud by the amil zakat who were appointed as zakat fund collector (Zainal et al., 2016). This leakage problems had attracted the attention of Muslim community and influence them to refused paying zakat through formal zakat institution. Another findings on the zakat distribution administered by higher learning institution showed that only part of the distribution authority is given to them and the remaining zakat funds need to submit to state zakat institution (Takril \& Othman, 2020).

\section{Overview of Majlis Agama Islam Melaka (MAIM) \& Pusat Zakat Melaka (PZM)}

In Malaysia, the establishment of Department of Waqaf, Zakat and Haji (JAWHAR) on 27 March 2004 aim to give more attention to zakat institution (Zainal et al., 2016). However, JAWHAR only being the coordinator and not having any executive power on any zakat institution. Each state in Malaysia have their own zakat institution under the organisation known as State Islamic Religious Council (SIRC), which wholly responsible in managing the collection and distribution of zakat. Although the legislation of managing zakat varies among states, but the main objective remains the same. Specifically in Melaka, SIRC is known as Majlis Agama Islam Melaka (MAIM). MAIM was instituted on 28 September 1960 with the aim to manage the affairs of the Islamic State of Melaka and assist His Majesty the Yang di-Pertuan Agong. The core activities of MAIM includes collecting funds from eligible Muslims and distribute them to the rightful beneficiaries through various benefit form such as food, shelter, education as well as health. 
MAIM as to date has three subsidiaries namely MAIM Holding Berhad, Al Khawarizmi Complex and Pusat Zakat Melaka (PZM). PZM is the organisation that been entrusted to carry out management of zakat fund effectively and systematically in accordance with the Islamic principle. Historically, all zakat management matters were under the responsibility of Waqf, Zakat and Baitulmal. In early 1993, Zakat Counter Computer (KZB) is introduced as to improved zakat payment process. The PZM's history was imprinted again on 1 April 2001, when it was corporatized and the scope of the task was divided, in which PZM was entrusted for the collection only while the scope of zakat distribution was under the management of Baitulmal, MAIM. PZM is established with a vision to become a top zakat organization in Malaysia by emphasizing on the concept of transparent management and implement zakat collection in a prudent, professional, efficient and systematic manner.

\section{Methodology}

This study used the document analysis method, where documents published either by the MAIM and PZM such as annual reports, bulletins and websites, online press reports by local media (for instance melakakini.my and bharian.com.my) as well as reports on social media, such as Facebook Zakat Melaka, were analysed for the collection of the required data. Data mainly on the zakat collection and zakat distribution were obtained from the annual reports of Majlis Agama Islam Melaka for years 2015 to 2019. Meanwhile, data on the governance framework for PZM were also collected based on annual reports, websites and any other published documents (such as local news, monthly bulletin of PZM \& MAIM, social medias platform). However, if data could not be found in these documents, information contained in the zakat centre was referenced by referring to officer in charge of PZM and sent an e-mail to obtain more information on activities in PZM particularly related to governance in zakat collection and zakat distribution. Based on inputs from the document analysis, the four aspects of good governance framework which are; (1) Accountable Board Leadership; (2) Transparent Information; (3) Disclosure Practices; and (4) Stakeholder Management were assessed by comparing data from the document analysis (stage one) with each rating index criterion and presented in the table.

\section{Results of The Study and Discussion}

This section reports the results of the analysis. The first section reports on the results of the performance of zakat collection and zakat distribution by PZM \& MAIM from year 2015 to 2019. The second section reports the results of the research on the good governance framework of PZM \& MAIM from year 2015 to 2019. The discussion of the results as follows: 


\section{Performance of Zakat Collection and Zakat Distribution in Melaka}

\section{Figure 1: Zakat Collection}

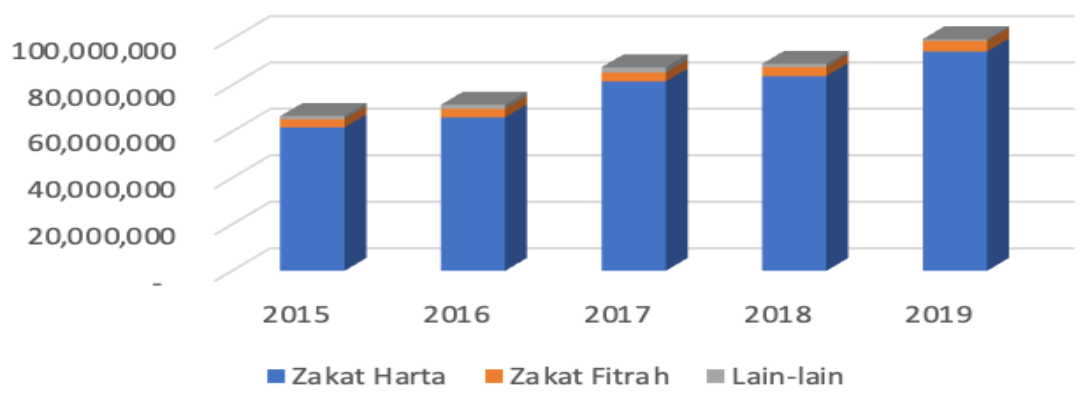

Figure 1 depicts the total collection of zakat Melaka between year 2015 to 2019. The chart shows that the zakat on wealth are the highest contribution of zakat collection in the range of 92 to 95 percent, followed by the zakat fitrah and others categories of zakat. According to Zakat Melaka, others zakat includes zakat on wealth that has been accrued from the payers and adjustments of zakat wealth from prior year. The trend for zakat collection in Melaka is increasing year to year albeit a little bit downward in 2018 but then back on to the increasing trend in year 2019. In year 2015, the zakat collection amounting to RM 66,653,328, and increase about 50 percent to RM 99,855,914 in year 2019. The phenomenon of rising awareness among the zakat payers resulted better zakat compliance among affordable Muslim and representing a positive value that mirror the Melaka citizen from 2015 to 2019.

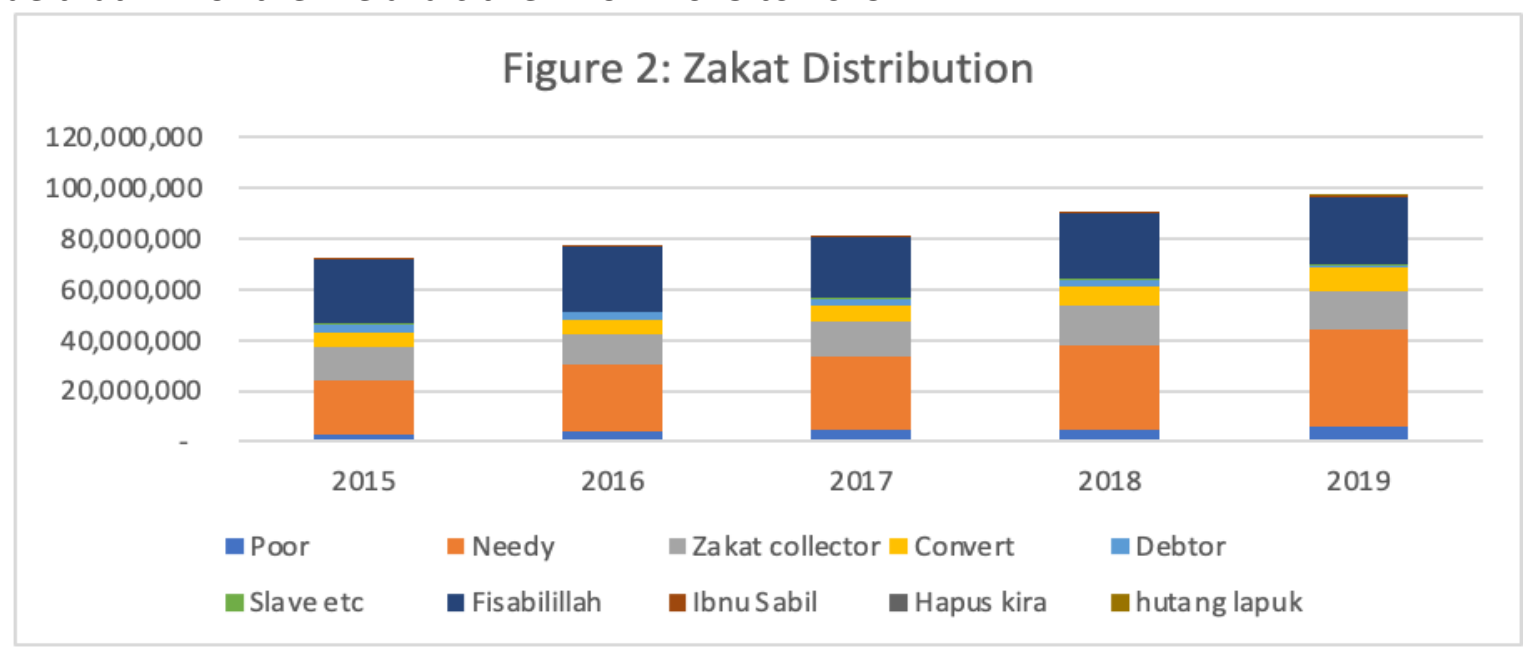

Zakat collection should be distributed to the beneficiaries (asnaf) that been mentioned clearly in the Holy Quran from Surah At Taubah verse 60: "Zakat is for the poor and the needy, and amil (those employed to administer the funds), for the muallaf (those who have embraced Islam), for those in bondage and in debt, those who strive in the cause of Allah and for the wayfarer; (thus it is) ordained by Allah and Allah is full of knowledge and wisdom". Figure 2 shows the zakat distributed by MAIM from year 2015 to 2019. The highest pay out of zakat for the asnaf are for the fisabilillah group about 36 percent (RM25.7 million) in year 2015 followed by the needy group 30 percent (RM21 million). Based on information received from MAIM officer through phone call conversation, asnaf fisabilillah in Melaka is referring to group of people who are struggling for their needs and for maslahah (public interest) programs. Some of the examples 
of distribution for asnaf fisabillillah are distribution for fisheries allowances, charity and religious programs, orphanage management, educational assistance, and human capital development program such as entrepreneurship program for asnaf.

However, the portion of distribution has changed in 2019 as about 39.5 percent (RM38 million) were allocated for the needy group. This raise a question why do the needy group increased in year 2019? Based on news published in Utusan Malaysia dated 3 June 2021, MAIM has introduced new application known as "Jejak Asnaf" since 2019 onwards to facilitate Melaka citizen to supply information on needy people around Melaka state directly to MAIM in order to receive zakat aid under MAIM within a shortest period. This apps able to ensure that no one has been left in receiving the zakat aid and ensure better efficiency and systematic work in delivering aids to the needy group within Melaka state. There are five functions available in this apps including applicant registration, status of asnaf information, complaint and feedback form regarding the distribution.

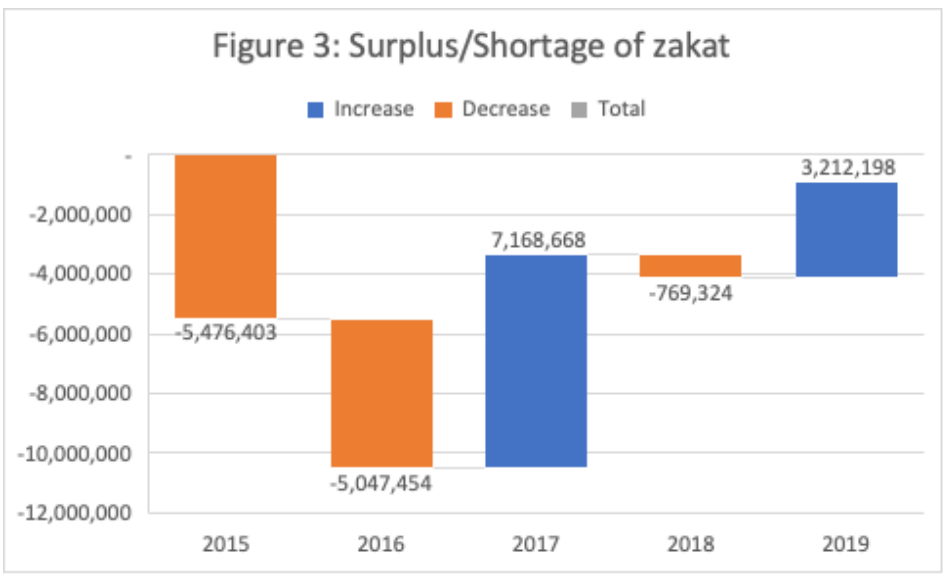

Zakat institutions are viewed performing well and efficient given that the distribution amount equate to the zakat collection. Figure 3 reports on the surplus/shortage zakat for the Zakat Melaka and indicating their performance. Surplus zakat means the amount of nondistributed zakat. The zakat surplus was calculated by subtracting the amount distributed from the total collection. As shown in Figure 3, the non-distributed zakat in year 2017 is quite high. However, once we shall remember that the zakat collection for the particular year will be distributed to the next year. Hence, it can be a shortage and surplus, while some amount is being carried forward. The shortage in year 2015, 2016 and 2018 implies that MAIM not only managed to distribute zakat collected in the current year but also distributed zakat of the previous year which had yet to be successfully distributed.

\section{Discussion on Good Governance Framework for Zakat Institution}

The governance of zakat institutions is the second hierarchy to be considered in observing its performance. Four components of governance framework are used in this study for the purpose of measuring the level of good governance in PZM \& MAIM namely composition of the accountable board leadership, official website for transparent information on zakat issues, disclosure practice in zakat annual report and stakeholder management in zakat distribution activities. As previously mentioned, all these data were derived from three main sources which 
INTERNATIONAL JOURNAL OF ACADEMIC RESEARCH ECONOMICS AND MANAGEMENT SCIENCES Vol. 10, No. 3, 2020, E-ISSN: 2226-3624 @ 2020 HRMARS

are annual report, zakat centre official website, and published mainstream news (i.e. Utusan Malaysia, Berita Harian, Melaka Kini News \& The Star).

Table 1: Elements of Good Governance Index in PZM and MAIM

\begin{tabular}{lccccc}
\hline & 2015 & 2016 & 2017 & 2018 & 2019 \\
\hline A. Accountable Board Leadership & & & & & \\
Composition of Board of Directors & Yes & Yes & Yes & Yes & Yes \\
Meetings of Board of Directors & Yes & Yes & Yes & Yes & Yes \\
Internal Audit Committee & No & No & No & Yes & Yes \\
$\begin{array}{l}\text { B. Transparent Information } \\
\text { Website Zakat Institution }\end{array}$ & Yes & Yes & Yes & Yes & Yes \\
Zakat Awareness Activities & Yes & Yes & Yes & Yes & Yes \\
Social Media & Yes & Yes & Yes & Yes & Yes \\
C. Disclosure Practice & & & & & \\
Audited Annual Report & Yes & Yes & Yes & Yes & Yes \\
D. Stakeholder Management & \multicolumn{2}{c}{} & & & \\
Zakat Distribution Activities & Yes & Yes & Yes & Yes & Yes \\
\hline
\end{tabular}

Table 1 portrays the level of zakat governance elements for PZM and MAIM from year 2015 to 2019. Generally, Zakat Melaka has fulfilled all the main principles highlighted in the standard governance index. First index, accountable board leadership lays the foundation for the profile of board directors in terms of its composition, frequent of meetings and the committee of internal audit. Interestingly, MAIM has change of their composition board of directors in every 3 years due to rotation basis and also some related to the current political situation in Melaka. The number of meetings of board directors were not stated in the annual reports, hence, we cross-checked with PZM \& MAIM through simple interviews and they did meetings two times per year or three depends on the matters to be discussed. For internal audit committee, MAIM \& PZM has established an internal audit unit under finance department since 2018 onwards where there is only one staff in charge for internal audit matters cum finance executive for the institution

The second item is the transparency of information provided by the official website of Zakat Melaka. The information provided in the official website of Zakat Melaka (https://www.izakat.com/ui.php) is quite comprehensive that cover all information related to zakat knowledges such as types of zakat wealth and its respective nisab, how to calculate zakat on wealth, how to pay zakat online through salary deduction, how to apply for zakat aid or how to report the availability of asnaf in your area and the list of zakat distribution activities. Meanwhile, Zakat Melaka also actively promoting their activities and information via social media platform particularly Facebook Zakat Melaka and Instagram @zakat.melaka. Hence, all the information being posted through these mediums have become as promotional activities and increase the awareness of zakat education among the zakat payers, asnaf as well as potential zakat payers in Melaka.

The third rating element is in terms of disclosure practice in annual report. Basically, the coverage of MAIM annual report is quite general that consists of its financial report (reporting total zakat collection and distribution for the year), report on MAIM's annual social activities, 
information on MAIM's board members, and any achievement and awards received by MAIM during the year. However, information regarding governance and sustainability report is not available in this annual report. Even though this annual report is not available to be access through online, MAIM has been showing good example whereby they disseminating the printed annual report to the various stakeholders and made it available through hardcopy in the MAIM office. Thus, for improvement purpose, PZM and MAIM should consider to widen the zakat Melaka financial information via online since this method is more accessible to the public and able to improve their relations with various parties.

The final item in the governance index is pertaining to the stakeholder management that focus on zakat distribution activities conducted by MAIM and PZM. Some of the distribution activities conducted in Melaka are Pre-Ramadhan Aid, 'Jejak Asnaf', Entrepreneurship Course for Asnaf, Workshop 'Skor Cemerlang', Raya Aid for Muallaf, Group Marriage for Muallaf, Kembara Muamalah, and Outreach Program. Generally, there are 10 types of aid schemes that has been introduced in Zakat Melaka for distribution which is conducted every year which are; 1) Monthly Food Aid; 2) Repair Asnaf Home Aid; 3) Single Mother Marriage Scheme Aid; 4) Critical/Chronic Illness Aid; 5) Spectacles Aid; 6) Volunteer Aid; 7) First House for Asnaf Aid; 8) Dialysis Treatment Aid; 9) School Fees Aid and 10) General Aid. All of these distribution initiatives are seen to be more proactive in order to reach out to the community and raise awareness on zakat payment obligations among potential zakat payers in Melaka.

\section{Conclusion}

In conclusion, the performance of zakat in MAIM \& PZM in terms of collection and distribution has been improving over the last five years (from 2015 to 2019) with increase of zakat compliance and distribution activities around Melaka. However, in terms of good governance elements in zakat institution, this study shown that the disclosure level of good governance practices is still not at optimum level though it is improving since 2018 onwards. Therefore, further improvement is required related to information need to disclose for governance report in MAIM \& PZM as well as providing an easy access of annual report to the public. This could enhance the transparency level in zakat institution and boost up the public confidence on how zakat institution manages zakat money efficiently and effectively. The implication of this study could provide the positive impact in zakat institutions when good governance is being practiced at ideal level; the result of zakat compliance and zakat distribution could be improved towards achieving Muslim prosperity not only for Melaka, but for the nation's economic sustainability. The result of this study also brings a significant contribution to the policymakers of zakat institution by concerning more on proper disclosure of corporate governance report for the benefit of the institution as well as its stakeholders. However, some limitation has found in this study since this study is only limited to governance for zakat institution in Melaka state, thus future research is recommended to be extend in analysing and measuring the good governance elements for each of the zakat institutions in Malaysia since zakat issues is being administered at state level with different locality, system and administration issues.

\section{Corresponding Author}

A'ieshah Abdullah Sani 
Centre of Islamic Philanthropy and Social Finance (CIPSF), Universiti Teknologi MARA, KM 26 Jalan Lendu, 78000, Alor Gajah,Melaka, Malaysia.

Email: aieshah124@uitm.edu.my

\section{Acknowledgment}

The authors would like to extend their gratitude to Universiti Teknologi MARA, Melaka, for funding this research through internal research grant 600-TNCPI 5/3/DDN (04) (031/2021).

\section{References}

Abdul Rahman, A. R. (2007). "Pre-Requisites for Effective Integration of Zakah Into Mainstream Islamic Financial System in Malaysia." Islamic Economic Studies 14(1\&2): 91-107.

Abd. Wahab, N., \& Abdul Rahman, A. R. (2011). "A Framework to Analyse the Efficiency and Governance of Zakat Institutions." Journal of Islamic Accounting and Business Research 2(1): 43-62.

Adiwijaya, Z. A., \& Suprianto, E. (2020). "Good Governance of Zakat Institutions: A Literature Review." Journal of Southwest Jiaotong University 55(2): 1-7.

Nazri, A. F. A., Abd Rahman, R., \& Omar, N. (2012). "Zakat and Poverty Alleviation : Roles of Zakat Institutions in Malaysia." International Journal of Arts and Commerce 1(7): 61-72.

Sawmar, A., \& Mohammed, M. O. (2021). "Enhancing Zakat Compliance through Good Governance: A Conceptual Framework." ISRA International Journal of Islamic Finance 13(1): 136-154.

Amalia, E. (2019). "Good Governance for Zakat Institutions in Indonesia: A Confirmatory Factor Analysis." Pertanika Journal of Social Sciences \& Humanities, 27 (3)

Endut, W. A., Taha, R., Ismail, S., Ahmad, N., \& Ali, M. N. N. (2020). "Financial Reporting Quality among Non-Profit Organisations in Malaysia." International Journal of Innovation, Creativity and Change 13(1): 939-50.

Ghazali, M. Z., Abdul Wahab, M. S., Saad, R. A. J., \& Samsudin, M. A. (2020). "Information Disclosure through Communication Channels by Zakat Institutions." e-Proceedings of 5th International Conference on E-Commerce, 59-64

Hussain, M. H. M., Idris, K. M., \& Saad, R. A. J. (2018). "Service Quality in Zakat Institution's Governance." Proceedings of the 5th International Conference on Accounting Studies (ICAS 2018), 16-17

Hambali, K. B. M. K., Hamzah, Z. L., Daud, M. Z., \& Johari, F. (2017) Managing the Institution of Zakat: Case Study of Muallaf in Selangor, Malaysia. In: MUTUM, D., BUTT, M., and RASHID, M. (eds.) Advances in Islamic Finance, Marketing, and Management. Bingley: Emerald Group Publishing Limited, 325-339.

IFAC and CIPFA. (2014), "International framework: good governance in the public sector", available at: www.ifac.org/system/files/publications/files/International-Framework-GoodGovernance-in-the-Public-Sector-IFAC-CIPFA.pdf (accessed 4 November 2016).

MCCG. (2012). "Malaysian Code on Corporate Governance" : 1-23.

Shazilli, M. S., Sa'adon, N. I., Ibrahim, R., Abdul Rahim, M., \& Ambali, A. R. (2012). "Good Governance in Zakat Distribution: Perceptions of Zakat Recipients at Kota Tinggi, Johor." ISBEIA 2012 - IEEE Symposium on Business, Engineering and Industrial Applications (October 2018): 619-24. 
Naz'aina. (2015). "The Effect of Internal Control System and Amil Competence on the Financial Reporting Quality at Zakat Management Institution Active Member of Zakat Forum in Special Capital City Region Jakarta and West Java Provinces." Procedia - Social and Behavioral Sciences 211: 753-60.

OECD. (2016). G20/OECD Principles of Corporate Governance. 2016. G20/OECD Principles of Corporate Governance.

Omar, N., \& Abu Bakar, K. M. (2012). "Fraud Prevention Mechanisms of Malaysian GovernmentLinked Companies: An Assessment of Existence and Effectiveness." Journal of Modern Accounting and Auditing 8(1): 15-31.

Ahmad, R. A., Othman, A. M., \& Salleh, M. S. (2015). "Assessing the Satisfaction Level of Zakat Recipients Towards Zakat Management." Procedia Economics and Finance 31(15), 140-51. http://dx.doi.org/10.1016/S2212-5671(15) 01141-7.

Saad, R. A. J., Idris, M. K., Shaari, H., Sawandi, N., \& Derashid, C. (2017). "Governance of NonProfit Organizations: A Case of Zakat Institutions in Malaysia." International Journal of Economic Research 14(16): 253-65.

Saad, R. A. J., Abdul Azis, N. M., \& Sawandi, N. (2014). "Islamic accountability framework in the zakat fund management" Procedia Social and Behavioural Sciences, 19 (8A), 3137-3142.

Samargandi, N., Tajularifin, M. S., Ghani, E. K., Abdul Aziz, A., \& Gunardi, A. (2018.) "Can Disclosure Practices and Stakeholder Management Influence Zakat Payers' Trust? A Malaysian Evidence." Business and Economic Horizons 14(4): 882-93.

Sapingi, R., Nelson, S. P., \& Obid, S. N. (2017). "Factors Affecting Disclosure Practices of Annual Report Zakat Institutions in Malaysia." Proceeding of The Malaysian National Economic Conference $12^{\text {th }}$ PERKEM 2017, 190-199

Sulaiman, H., Che Cob, Z., \& Ali, N. (2015). "Big Data Maturity Model for Malaysian Zakat Institutions to Embark on Big Data Initiatives." 2015 4th International Conference on Software Engineering and Computer Systems, ICSECS 2015: Virtuous Software Solutions for Big Data: 61-66.

Takril, N. F., \& Othman, N. F. (2020). "Effectiveness of Zakat Collection and Distribution of Zakat Counter at Higher Learning Institutions." International Journal of Islamic Economics and Finance Research 3(2): 91-106.

Tazali, M. S. (2021). "Melaka Bangunkan Aplikasi Jejak Asnaf." Utusan Malaysia. https://www.utusan.com.my/berita/2021/06/melaka-bangunkan-aplikasi-jejak-asnaf/

Zadjuli, S. I., Shofawati, A., \& Muryani. (2020). "Implementing Good Corporate Governance in Zakat Institution." Bussecon Review of Social Sciences 2(1): 27-37.

Zainal, H., Basarud-din, S. K., Yusuf, M. R., \& Omar, S. N. Z. (2016). "Managing Zakat Fund in Malaysia." Journal of Global Business and Social Entrepreneurship 1(2): 46-53. 